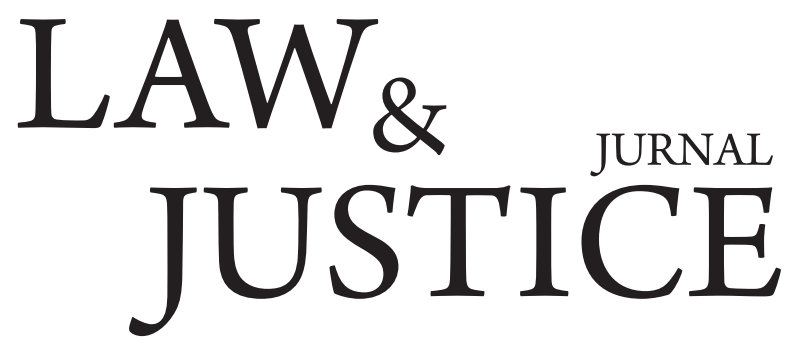

\title{
EKSISTENSI PENDAFTARAN RAHASIA DAGANG DAN IMPLEMENTASI PERLINDUNGANNYA (STUDI DI KANWIL KEMENKUMHAM JAWA TENGAH)
}

\author{
Andry Setiawan \\ Department of Private and Commercial Law \\ Faculty of Law, Universitas Negeri Semarang Semarang, Indonesia \\ Email: andry_style@yahoo.co.id \\ Dewi Sulistianingsih \\ Department of Private and Commercial Law \\ Faculty of Law, Universitas Negeri Semarang, Semarang, Indonesia \\ Corresponding email: dewisulistianingsih21@gmail.com \\ Rindia Fanny Kusumaningtyas,S.H.,M.H. \\ Department of Private and Commercial Law \\ Faculty of Law, Universitas Negeri Semarang Semarang, Indonesia \\ Email: rndhukum@gmail.com
}

\begin{abstract}
Abstrak
Kekayaan Intelektual (KI) merupakan kekayaan yang timbul atau lahir dari kemampuan intelektual manusia. Kekayaan Intelektual (KI) merupakan hak untuk menikmati hasil kreativitas intelektual manusia secara ekonomis. Kekayaan Intelektual terbagi menjadi dua, yaitu hak cipta dan hak milik industri yang di antaranya merek, paten, desain industri, rahasia dagang, desain tata letak sirkuit terpadu. Rahasia dagang termasuk bagian dari kekayaan intelektual yang dilindungi oleh undangundang guna menjamin kepastian hukum bagi pemegang hak rahasia dagang karena mempunyai nilai ekonomi yang tinggi. Oleh karena itu pemegang hak harus mendapatkan perlindungan hukum yang jelas dan mendapat kepastian hukum oleh negara. Berdasarkan latar belakang tersebut maka muncullah perumusan masalah yang pertama bagaimana eksistensi pendaftaran rahasia dagang di Kementerian Hukum dan HAM Jawa Tengah dan yang kedua bagaimana karakteristik informasi rahasia dagang dan perlindungan hukumnya. Tujuan yang ingin dicapai dalam penelitian ini adalah untuk mengetahui dan menganalisis bagaimana eksistensi pendaftaran rahasia dagang di Kementerian Hukum dan HAM Jawa Tengah serta untuk mengetahui dan menganalisis bagaimana informasi rahasia dagang dan perlindungan hukumnya. Metode yang digunakan dalam penelitian ini metode kualitatif dengan pendekatan yuridis empiris yaitu suatu penelitian yang meneliti peraturan-peraturan hukum yang kemudian dihubungkan dengan data dan perilaku yang hidup di tengah-tengah masyarakat langsung. Dari hasil penelitian terdapat rahasia dagang yang didaftarkan pada Direktorat Jenderal Kekayaan Intelektual Kementerian
\end{abstract}




\section{Eksistensi Pendaftaran Rahasia Dagang ...}

Hukum dan HAM Jawa Tengah untuk mendapatkan perlindungan hukum walaupun pendaftaran rahasia dagang tidak diwajibkan dalam undang-undang. Mengenai perlindungan hukum rahasia dagang diatur dalam hukum pidana maupun perdata.

Kata Kunci: Rahasia dagang, Kekayaan Intelektual, Pendaftaran Rahasia Dagang

\section{Pendahuluan}

Ide, gagasan, atau informasi merupakan hal penting bagi setiap orang atau perusahaan. Bisa jadi ide, gagasan, atau informasi tersebut memiliki nilai ekonomis yang tinggi. Hanya tinggal bagaimana orang tersebut mewujudkan ide atau gagasan tersebut menjadi sesuatu yang bernilai dan membuat informasi tersebut menjadi berharga atau bahkan lebih berharga. Banyak cara untuk membuat hal itu dapat terwujud. Tindakan apapun yang dilakukan pastilah tindakan yang sudah dipertimbangkan sedemikian rupa baik akibat maupun keuntungan dan kerugian akan hal tersebut. Bisa jadi seseorang menyimpan sebuah rahasia agar tetap terjaga menjadi sebuah informasi yang bersifat rahasia, sampai waktunya akan dibuka di ruang publik. Akan menjadi suatu persoalan, manakala seseorang tidak paham akan tindakan yang harus dilakukannya terhadap ide, gagasan, atau informasi tersebut sehingga mengakibatkan ia kehilangan keuntungan secara ekonomis yang seharusnya dia dapatkan.

Betapa pentingnya suatu informasi, ide, atau gagasan bagi dunia usaha manakala informasi, ide, atau gagasan tersebut merupakan hal pokok dalam bisnis yang akan atau sedang dibangun ${ }^{1}$. Pelaku usaha merahasiakan informasi, ide, atau gagasannya, agar bisnis atau usaha yang dibangunnya berjalan lancar. Bagi pelaku usaha, informasi yang bersifat rahasia akan sangat penting demi keberlangsungan usahanya. Setiap usaha/bisnis akan selalu memiliki informasi yang bersifat rahasia dan masuk sebagai kategori rahasia, yaitu rahasia dagang. Rahasia dagang bisa dikatakan rumit jika pemilik rahasia dagang tidak paham mengenai arti penting trade secret bagi usaha atau bisnisnya. Penting bagi pelaku usaha untuk memahami akan arti penting trade secret itu sendiri. Rahasia dagang sangat berharga dan memiliki banyak keuntungan bagi pemiliknya. Hanya jika pemilik trade secret mampu

$1 \quad$ Michael Risch, Why Do We Have Trade Secrets?, 11 Intellectual Property L. Rev. 1 (2007). Available at: http://scholarship.law.marquette.edu/iplr/vol11/iss1/1. mengelolanya lebih baik. Pengelolaan yang tidak baik akan mengakibatkan pemilik rahasia dagang akan kehilangan daya kompetitifnya atau ciri khas yang merupakan aset yang berharga bagi pemilik trade secret.

Secara garis besar, rahasia dagang adalah semacam informasi yang memiliki nilai karena tidak diketahui secara umum. Banyak informasi berharga mungkin muncul sepele dan karena itu mungkin tidak cukup dihargai, banyak pelaku usaha (pengusaha) tidak menyadari akan hal tersebut. Pelaku usaha (pengusaha) akan menyadari pentingnya rahasia dagang pada saat pesaing/ kompetitor mereka mencoba untuk mendapatkan pelanggannya atau rencana pemasaran mereka atau dengan melakukan pendekatan/pembicaraan dengan para karyawan agar dapat mengetahui rahasia dagang yang dimiliki oleh pelaku usaha tersebut. Pelaku usaha, baru akan menyadari bahwa mereka memiliki sesuatu yang berharga untuk dilindungi. Semakin pelaku usaha tersebut menyadari bahwa informasi yang berharga atau pengetahuanmerekadibutuhkan agardapatmenang dalam kompetisi bisnis, maka pelaku usaha akan mulai melakukan upaya untuk melindungi rahasia dagangnya. Kemajuan teknologi dan kreativitas yang semakin berkembang pesat menyebabkan adanya kebutuhan untuk menyimpan (agar tidak diketahui oleh publik) suatu formula, resep, rumus dan sebagainya, yang memiliki nilai ekonomis bagi pemegangnya dan dijaga kerahasiannya ${ }^{2}$.

\section{Metode Penelitian}

Metode pendekatan yang dipergunakan dalam penelitian ini adalah yuridis empiris, yaitu cara atau prosedur yang digunakan untuk memecahkan masalah penelitian dengan meneliti data sekunder terlebih dahulu untuk kemudian dilanjutkan dengan meneliti data primer yang ada di lapangan. Data primer adalah data yang diperoleh langsung dari masyarakat. Aspek yuridis digunakan

2 Friedman, David D., William M. Landes, and Richard A. Posner. 1991. "Some Economics of Trade Secret Law."Journal of Economic Perspectives, 5 (1): 61-72. 
sebagai acuan dalam menilai atau menganalisis permasalahan berdasarkan aspek hukum yang berlaku, yaitu dengan mengkaji peraturanperaturan hukum mengenai rahasia dagang serta peraturan terkait di bawahnya yang mempunyai korelasi dengan penelitian ini. Sedangkan pendekatan empiris, yaitu dengan melakukan penelitian yang bertujuan untuk memperoleh pengetahuan empiris dengan jalan terjun langsung ke lapangan mengenai segala sesuatu yang terkait dengan pendaftaran rahasia dagang khususnya di Kantor Wilayah Kementerian Hukum dan HAM Jawa Tengah.

Spesifikasi penelitian yang digunakan dalam penelitian ini adalah deskriptif analitis, artinya hasil penelitian ini berusaha memberikan gambaran secara menyeluruh, mendalam tentang suatu keadaan atau gejala yang diteliti. Suatu penelitian deskriptif menekankan pada penemuan fakta-fakta yang digambarkan sebagaimana keadaan sebenarnya, dan selanjutnya data maupun fakta tersebut diolah dan ditafsirkan. Penelitian deskriptif dimaksudkan untuk memberikan data yang seteliti mungkin tentang objek yang diteliti, keadaan, atau gejala-gejala lainnya. Penelitian ini bersifat deskriptif karena dengan penelitian ini diharapkan akan diperoleh suatu gambaran yang bersifat menyeluruh dan sistematis mengenai eksistensi pendaftaran rahasia dagang di Kantor Wilayah Kementerian Hukum dan HAM Jawa Tengah, kemudian dilakukan suatu analisis terhadap data yang diperoleh dan pada akhirnya didapat pemecahan masalah.

Jenis data yang digunakan dalam penelitian ini adalah data primer dan data sekunder. Data primer merupakan data yang diperoleh dari lokasi penelitian. Sumber data primer diperoleh dari Bidang Pelayanan Hukum Kantor Wilayah Kementerian Hukum dan HAM Jawa Tengah. Sementara data sekunder merupakan data yang dapat mendukung keterangan-keterangan atau menunjang kelengkapan data primer.

Metode analisis data yang digunakan adalah metode kualitatif, yaitu data yang diperoleh disusun secara sistematis kemudian dianalisis secara kualitatif agar dapat diperoleh kejelasan masalah yang dibahas. Tujuan digunakannya analisis kualitatif ini adalah untuk mendapatkan informasi mengenai eksistensi pendaftaran rahasia dagang di Jawa Tengah. Analisis data kualitatif adalah suatu cara penelitian yang menghasilkan data deskriptif analitis, yaitu apa yang dinyatakan oleh responden secara tertulis/lisan dan juga perilakunya yang nyata, diteliti, dan dipelajari secara utuh.

Metodologi kualitatif adalah prosedur penelitian yang menghasilkan data deskriptif berupa kata-kata tertulis atau lisan dari orangorang dan perilaku yang dapat diamati. Setelah analisis data selesai, maka hasilnya akan disajikan secara deskriptif yaitu dengan menuturkan dan menggambarkan apa adanya sesuai dengan permasalahan yang diteliti. Dari hasil tersebut, kemudian dapat ditarik kesimpulan yang merupakan jawaban atas permasalahan yang diangkat dalam penelitian ini.

\section{Hasil dan Pembahasan}

Rahasia dagang dikenal juga dengan sebutan Undisclosed Information (WTO/TRIPs) atau Confidential Information (Inggris), atau Trade Secret (Amerika), dan Indonesia menyebutnya rahasia dagang, yang merupakan alih bahasa dari Trade Secret. Rahasia dagang merupakan bagian dari sistem Hak Kekayaan Intelektual yang patut diberi perlindungan sebagaimana objek HKI lainnya, seperti Hak Cipta, Hak Merek, Hak Paten, Hak Desain Industri, d1l ${ }^{3}$. Rahasia dagang didefinisikan sebagai informasi termasuk suatu rumus, pola-pola, kompilasi, program, metode teknik atau proses yang menghasilkan nilai ekonomis secara mandiri, nyata, dan potensial.

\section{Eksistensi Pendaftaran Rahasia Dagang di Kementerian Hukum dan HAM Jawa Tengah}

Globalisasi saat ini ditandai dengan kemajuan teknologi dan informasi yang bernilai guna dan jual tinggi hanya saja hal ini sangat rawan akan adanya penjiplakan, pencurian, dan penyalahgunaan terhadap hasil karya manusia yang dapat memajukan ekonomi. Akibat kerugian tersebut maka perlu adanya upaya untuk memulihkan keadaan kembali seperti semula. Hukum yang berkaitan dengan kekayaan intelektual yang akan memberikan perlindungan hukum atas kreativitas yang sangat menguntungkan dan memiliki nilai ekonomi. H.S. Kartadjoemena menyatakan GATT

3 Robert G. Bone, The (Still) Shaky Foundations of Trade Secret Law, Texas Law Review, Vol. 92:18031838 (2014). 
adalah sebagai forum penyelesaian sengketa sebagai suatu forum internasional yang merupakan instrumen untuk menangani masalah perdagangan dunia $^{4}$.

Hukum rahasia dagang terbentuk dari berbagai kasus yang memiliki elemen kontrak, kejujuran kekayaan, kewajiban berdasarkan kepercayaan dan itikad baik ${ }^{5}$. Jika kita menyimak pertimbangan hukum dibentuknya UU Rahasia Dagang (UURD), ada 2 alasan mengapa Indonesia perlu memiliki UU yang khusus mengatur dan melindungi hak rahasia dagang, yaitu: (a) Untuk memajukan industri yang mampu bersaing dalam lingkup perdagangan nasional dan internasional perlu diciptakan iklim yang mendorong kreasi dan inovasi masyarakat dengan memberikan perlindungan hukum terhadap rahasia dagang sebagai bagian dari sistem hak kekayaan intelektual; (b) Untuk memenuhi tuntutan Agreement Establishing the World Trade Organization (Persetujuan Pembentukan Organisasi Perdangan Dunia) yang mencakup Agreement of Trade Related Aspect of Intellectual Property Rights (Persetujuan TRPs) yang telah diratifikasi dengan UU No. 7 Tahun 1994 Tentang Pengesahan Agreement Establishing The Word Trade Organization (Persetujuan Pembentukan Organisasi Perdagangan Dunia).

Bahwa dengan dibentuk Undang-Undang Rahasia Dagang dalam rangka mencapai tujuan sebagai berikut ${ }^{6}$ : (a) Memajukan industri di Indonesia; (b) Menumbuhkan kembangkan invensi-invensi baru yang dapat memajukan industri tersebut; (c) Melindungi kepentingan hukum terhadap invensi, terutama invensi baru; (d) Menjamin kepastian hukum bagi invensi tidak ada pelanggaran terhadap hak rahasia dagang miliknya.

Penerapan dan pelaksanaan perlindungan hukum terhadap Rahasia Dagang secara komprehensif sebenarnya telah terjadi sebelum berlakunya pengaturan UU No. 30 Tahun 2000. Pengelompokan istilah rahasia dagang ke dalam

$4 \quad$ I Made Udiana, Rekonstruksi Pengaturan Penyelesaian Sengketa Penanaman Modal Asing, (Udayana: University Press, 2011), hlm 4.

5 Suyud Margono \& Amir Angkasa, Komersialisasi Aset Intelektual (Aspek Hukum Bisnis), (Jakarta: PT. Gramedia Widyasarana Indonesia, 2002), hlm 39.

6 Adami Chazawi, Tindak Pidana Hak Atas Kekayaan Intelektual (HAKI), (Malang: Bayu Media Publishing, 2007), hlm 205-206.
Kekayaan Intelektual dalam instrumen hukum nasional mulai muncul pada tahun 1997, ketika pemerintah Republik Indonesia mengeluarkan Peraturan Pemerintah (PP) No. 16 Tahun 1997 tentang waralaba. Dalam penjelasan pasal 1 angka 1 PP tersebut dinyatakan bahwa yang dimaksud dengan Hak atas Kekayaan Intelektual mengikuti antara lain Merek, Nama Dagang, Logo, Desain, Hak Cipta, Rahasia Dagang dan Paten.

Ketentuan lain yang secara eksplisit memasukkan rahasia dagang sebagai salah satu bagian dalam kekayaan intelektual adalah pasal 50 b UU No. 5 Tahun 1999 tentang larangan praktik monopoli dan persaingan usaha tidak sehat. Ketentuan ini telah makin mengukuhkan kedudukan rahasia dagang sebagai suatu bentuk hak eksklusif, bahkan hak yang dikecualikan dari objek yang termasuk larangan praktik monopoli dan persaingan usaha tidak sehat, walaupun ketentuan tersebut belum dapat menjawab substansi pengaturan perlindungan rahasia dagang secara terperinci sebelum lahirnya UU No. 30 Tahun 2000 tentang rahasia dagang yang mengatur secara khusus.

Pengelompokkan rahasia dagang ke dalam kekayaan intelektual memberikan konsekuensi yuridis, di mana rahasia dagang kini memiliki perlindungan yang sifatnya lebih permanen dan spesifik melalui UU No. 30 Tahun 2000 tentang rahasia dagang. Apabila sebelumnya pelanggaran terhadap hal yang berkaitan dengan rahasia dagang akan berhadapan dengan pasal-pasal yang sifatnya agak luas seperti ketentuan pidana dan perdata pada umumnya, maka selanjutnya pada saat diundangkannya UU No. 30 Tahun 2000 para pelanggar akan berhadapan dengan suatu aturan perundang-undangan yang sifatnya lebih spesifik dalam UU ini.

Pemilik rahasia dagang wajib melindungi informasinya yang bersifat rahasia dan memiliki nilai ekonomis, dimana pemilik tersebut juga harus mempunyai pola untuk menyampaikan informasinya dalam hal keperluan bisnis dengan cara yang tertata dan layak sebagaimana dijelaskan dalam Pasal 3 Undang-Undang Nomor 30 Tahun 2000 tentang Rahasia Dagang. Kewajiban untuk menjaga kerahasiaan timbul karena adanya hubungan hukum antara satu pihak dengan pihak lain. Salah satu hubungan hukum yang timbul adalah hubungan antara pengusaha dengan buruh atau pegawai dengan majikan. 
Undang-Undang Nomor 30 Tahun 2000 Tentang Rahasia Dagang tidak mengatur secara spesifik mengenai prinsip yang dianut dalam rahasia dagang sebagai bagian dari kekayaan intelektual. Kekayaan intelektual menganut dua prinsip dalam melakukan perlindungan hukum yakni: first to file system dan first to use system. First to file system merupakan sistem pendaftaran ini didasarkan pada pendaftaran pertama. Artinya, jika ada dua orang mendaftarkan kekayaan intelektual pada hari yang sama dengan objek yang sama, pihak yang mendaftarkan terlebih dahululah yang dipriotaskan untuk diproses. Sedangkan first to use system didasarkan pada pengguna pertama. Artinya, pemilik kekayaan intelektual yang akan didaftar adalah orang pertama yang meggunakan kekayaan intelektual tersebut. Amerika adalah satu-satunya negara yang menganut sistem pendaftaran ini.

Untuk rahasia dagang sendiri karena sifat kerahasiaannya tidak diwajibkan menganut sistem tersebut karena dalam Pasal 3 UndangUndang Nomor 30 tahun 2000 tentang Rahasia Dagang menyatakan bahwa rahasia dagang akan mendapat perlindungan apabila informasi tersebut bersifat rahasia, mempunyai nilai ekonomi, dan dijaga kerahasiaannya melalui upaya sebagaimana mestinya. Informasi dianggap bersifat rahasia apabila informasi tersebut hanya diketahui oleh pihak tertentu atau tidak diketahui secara umum oleh masyarakat. Informasi dianggap memiliki nilai ekonomi apabila sifat kerahasiaan informasi tersebut dapat digunakan untuk menjalankan kegiatan atau usaha yang bersifat komersial atau dapat meningkatkan keuntungan secara ekonomi. Informasi dianggap dijaga kerahasiaannya apabila pemilik atau para pihak yang menguasainya telah melakukan langkah-langkah yang layak dan patut.

Pasal tersebut menjelaskan bahwa rahasia dagang tidak termasuk dalam first to file system karena tidak ada pembahasan dalam undangundang rahasia dagang mengenai pendaftaran. Akan tetapi, apabila ditarik dalam first to use system akan sukar dibuktikan siapa pemegang haknya apabila terjadi masalah terhadap rahasia dagang. Oleh karena itu kerahasiaan yang terdapat pada rahasia dagang berbeda dengan hak cipta yang menganut siapa yang pertama kali memublikasikan ialah pemiliknya. Namun, dalam hal pengalihan rahasia dagang wajib dicatatkan di Direktorat Jenderal yang saat ini adalah Dirjen
Kekayaan Intelektual Kementerian Hukum dan HAM serta diumumkan dalam berita umum rahasia dagang.

Rahasia dagang memang tidak diwajibkan didaftarkan pada Dirjen Kekayaan Intelektual Kementerian Hukum dan HAM untuk mendapatkan perlindungan Hukum, akan tetapi untuk mendapatkan pengakuan dan pembuktian mengenai kepemilikan rahasia dagang, ada pemilik rahasia dagang yang mendaftarkan rahasia dagangnya pada Direktorat Jenderal Kekayaan Intelektual Kementerian Hukum dan HAM Jawa Tengah. Namun, peneliti tidak dapat mengakses lebih jauh terkait bentuk rahasia dagang yang telah didaftarkan tersebut dan mekanisme pendaftarannya dikarenakan pihak dari Direktorat Jenderal Kekayaan Intelektual Kementerian Hukum dan HAM Jawa Tengah merahasiakan hal tersebut. Undang-Undang Nomor 30 Tahun 2000 tentang rahasia dagang juga tidak mengatur secara jelas mengenai tata cara dan syarat-syarat pendaftarannya dan tidak juga mewajibkan rahasia dagang untuk didaftarkan.

Adanya pemilik rahasia dagang yang telah mendaftarkan rahasia dagangnya juga untuk menjaga kerahasiaan rahasia dagang, dengan adanya pendaftaran maka pemilik rahasia dagang tidak perlu khawatir mengenai pembuktian kepemilikan rahasia dagang apabila terjadi masalah ke depannya. Direktorat Jenderal Kekayaan Intelektual bisa menjadi saksi dalam hal menyelesaikan masalah mengenai kepemilikan rahasia dagang. Walaupun undang-undang tidak mengatur mengenai kewajiban pemilik rahasia dagang untuk mendaftarkan rahasia dagangnya. Dengan demikian, pemilik rahasia dagang hanya perlu menyimpan dan merahasiakan rahasia dagangnya supaya tidak diketahui oleh umum dan tetap mendapatkan perlindungan hukum.

Berbeda pendaftaran rahasia dagang yang tidak diatur secara jelas dalam undang-undang rahasia dagang, mengenai pengalihan rahasia dagang dalam Undang-Undang No 30 Tahun 2000 tentang rahasia dagang wajib dicatatkan pada Dirjen Kekayaan Intelektual Kementerian Hukum dan HAM supaya mendapatkan kepastian hukum. Hal ini seakan-akan menjadi suatu yang tidak konsekuen terhadap aturan yang terdapat pada rahasia dagang karena rahasia dagang tidak wajib didaftarkan dan pemilik atau pemegang hak rahasia dagang hanya perlu merahasiakan rahasia 
dagang supaya tidak diketahui oleh umum, tapi dalam proses pengalihan rahasia dagang justru wajib dicatatkan di Direktorat Jenderal Kekayaan Intelektual Kementerian Hukum dan HAM. Dengan telah dialihkannya rahasia dagang maka dapat disimpulkan bahwa bukan hanya para pihak saja yang mengetahui rahasia dagang akan tetapi Direktorat Jenderal Kekayaan Intelektual juga mengetahui tentang rahasia dagang tersebut yang dialihkan. Sehingga kerahasiaan mengenai rahasia dagang juga telah diketahui oleh Direktorat Jenderal Kekayaan Intelektual Kementerian Hukum dan HAM.

Eksistensi pendaftaran rahasia dagang memang tidak populer seperti kekayaan intelektual lainnya karena menurut penelitian yang telah peneliti lakukan di Direktorat Jenderal Kekayaan Intelektual Kementerian Hukum dan HAM Jawa Tengah hanya terdapat 8 (delapan) pemegang hak rahasia dagang yang mendaftarkan rahasia dagangnya.

\section{Perlindungan Rahasia Dagang: Suatu Kebutuhan}

Sulitnya melakukan perlindungan terhadap rahasia dagang menjadi suatu perhatian di setiap negara. Pada prinsipnya rahasia tidak hanya dapat dilindungi oleh moral dan agama tetapi juga oleh hukum. Salah satu fungsi hukum adalah memberikan perlindungan terhadap kepentingan manusia. Sementara agar kepentingan manusia terlindungi, maka hukum harus dilaksanakan dan ditegakkan. Hukum mencerminkan nilai-nilai keadilan, kesejateraan. Hukum juga diharapkan mencerminkan sistem nilai, baik sebagai sarana yang melindungi nilai-nilai maupun sebagai sarana mewujudkan dalam tingkah laku masyarakat. Hukum sebagai suatu peraturan yang logis dan konsisten apabila dalam suatu peraturan perundang-undangan yang dibuat itu secara efektif dan didukung oleh sarana-sarana yang menandai. Hukum melindungi pemilik rahasia dagang dari perbuatan pihak lain yang dapat merugikan si pemilik rahasia dagang.

Rahasia dagang, yaitu informasi yang dianggap rahasia di bidang teknologi dan/atau bisnis. Perlindungan itu sendiri secara otomatis diberikan terhadap informasi yang dianggap rahasia tersebut sepanjang informasi tersebut bersifat rahasia, mempunyai nilai ekonomis dan dijaga kerahasiaannya melalui upaya sebagaimana mestinya. Sehingga hak rahasia dagang tidak memiliki jangka waktu perlindungan. Sepanjang kriteria informasi tersebut dipertahankan maka perlindungan rahasia dagang tetap berlaku terhadap informasi tersebut. Suatu informasi dianggap rahasia apabila hanya diketahui oleh pihak-pihak tertentu saja, misalnya informasi perusahaan yang hanya diketahui oleh direktur dari perusahaan tersebut. Suatu informasi dianggap mempunyai nilai ekonomis apabila dapat dijalankan untuk kegiatan atau usaha yang bersifat komersial atau dapat meningkatkan keuntungan secara ekonomi, misalnya daftar klien, daftar supplier barang dari suatu perusahaan, dsb. Oleh karena itu, informasi yang bersifat detail dapat memberikan keuntungan ekonomis dari suatu perusahaan. Suatu informasi dianggap dijaga kerahasiaannya apabila pemiliknya telah melakukan langkahlangkah yang layak atau patut misalnya suatu formula makanan disimpan dalam suatu safe deposit box begitu juga dengan pembuatan perjanjian kerahasiaan antara perusahaan dengan karyawannya atau pihak ketiga ${ }^{7}$.

Mekanisme perlindungan rahasia dagang adalah sepenuhnya diupayakan oleh sang pemilik rahasia dagang, dijaga kerahasiaanya agar tidak terbuka kepada masyarakat. Oleh karena itu, jangka waktu perlindungan rahasia dagang adalah selama rahasia dagang tersebut belum terbuka. Rahasia dagang tidak ada pendaftaran. Rahasia dagang tidak diperlukan pendaftaran. Rahasia dagang hanya tersimpan oleh pemilik informasi rahasia dagang itu sendiri. Hak kekayaan intelektual ini istimewa karena tidak perlu didaftarkan dan tidak perlu diumumkan untuk mendapatkan perlindungan hukum.

In this, secretinformation has to be maintained and provide a competitive advantage to its owner may qualify for trade secret protection. A trade secret protection is unlike patent and copyright protection because it must be kept secret. In this trade secret owner must not apply in the government for the protection. In this owner simply establish and maintain trade secrets as an internal matter ${ }^{8}$.

7 Robert G. Bone, A New Look at Trade Secret Law: Doctrine in Search of Justification, 86 CALIF. L. Rev. 241 (1998). https://doi.org/10.15779/Z38942G

8 Sarika Choudhary, et al, Program and Data Protection: Copyright, Patent, Trade Secret and Trademark, Indian Journal of Computer Science and Engineering (IJCSE), 
Hak atas rahasia dagang meliputi hak untuk menggunakan sendiri rahasia dagangnya dan hak untuk memberikan lisensi kepada atau melarang pihak lain untuk menggunakan atau mengungkapkan rahasia dagang tersebut kepada pihak ketiga untuk kepentingan komersial ${ }^{9}$. Perlindungan rahasia dagang dalam hak kekayaan intelektual memang tergolong unik. Hal ini didasari oleh karakteristik rahasia dagang yang sangat berbeda dengan hak kekayaan intelektual lainnya seperti merek, paten, desain industri, desain tata letak sirkuit terpadu. Informasi rahasia yang dipergunakan dalam perdagangan dapat dikatakan sebagai suatu ide atau gagasan yang berasal dari intelektual manusia yang perlu juga untuk dilindungi karena persoalan keadilan dan penghargaan bagi si pemilik rahasia dagang. Tidak setiap informasi yang bersifat rahasia dalam perdagangan akan selalu mendapatkan perlindungan dari kekayaan intelektual. Tidak mudah pula mengkategorikan bahwa informasi dalam perdagangan tersebut masuk sebagai rahasia dagang.

Tidak semua informasi yang bersifat rahasia adalah trade secret. Ada beberapa faktor yang digunakan untuk menentukan apakah rahasia tersebut dapat memenuhi syarat sebagai rahasia dagang. Faktor tersebut yaitu mengenai sejauh mana tindakan yang dilakukan oleh pemilik rahasia untuk menjaga kerahasiaan informasi tersebut. Tindakan tersebut mengatur segala kemudahan dan kesulitan untuk informasi yang dapat diketahui oleh orang lain. Berdasarkan pertimbangan ini, aturan umumnya adalah informasi tersebut dapat dilindungi sebagai rahasia dagang. Jika informasi tersebut telah menyebar luas ke publik maka informasi tersebut bukan lagi disebut sebagai rahasia dagang. Jika diambil tindakan pengamanan yang memadai untuk merahasiakan informasi tersebut agar tidak diketahui oleh umum, maka informasi tersebut masih dianggap rahasia dagang. Pemilik rahasia dagang dapat memberitahukan rahasia dagang tersebut kepada orang lain asalkan mereka berjanji untuk tidak mengungkapkan rahasia dagang tersebut kepada orang lain. Pemilik rahasia dagang harus waspada terhadap janji tersebut dan harus mengantisipasi

Vol. 4 No.3, Jun-Jul 2013, hlm 235-239.

9 John Hull; Trade secret licensing: the art of the possible, Journal of Intellectual Property Law \& Practice, Volume 4, Issue 3, 1 March 2009, Pages 203212, https://doi.org/10.1093/jiplp/jpn251 jika janji tersebut tidak ditepati. Pertanyaan yang paling mendasar adalah bagaimana jika seseorang/ pelaku usaha kehilangan informasi rahasia dagang mereka karena telah memberitahukan kepada orang lain meskipun telah ada perjanjian bahwa orang yang diberitahukan informasi yang rahasia tersebut untuk tidak mengungkapkannya kepada yang lain. Apalagi pemberian informasi rahasia dagang tersebut hanya didasarkan pada kepercayaan saja.

Setiap pihak, dalam hal ini pegawai dari perusahaan pemilik rahasia dagang dan juga pegawai pemerintah yang melakukan pemeriksaan tersebut memiliki kewajiban hukum untuk tidak membuka informasi yang telah diperolehnya. Jika ternyata terjadi kebocoran informasi yang dilakukan oleh pihak yang tidak berhak, pemilik rahasia dagang tersebut dapat menuntut pihak yang membuka rahasia dagang dengan berdasar pada pasal 13, 14, dan 17 UU No 30 Tahun 2000 tentang Rahasia Dagang.

Indonesia membuat peraturan tentang rahasia dagang, agar warga Indonesia mampu melakukan persaingan jujur dan sehat dalam pasar nasional maupun pasar global. Pengusaha Indonesia dipersiapkan untuk bersaing dan memasuki persaingan usaha, maka pemerintah Indonesia memperhatikan setiap pelaku usaha dan melindungi hak-haknya agar tidak terjadi persaingan tidak sehat yang sangat rentan dalam rahasia dagang. Usaha yang rentan terjadi persaingan tidak sehat adalah rumah makan yang termasuk dalam bidang makanan, di mana informasi mengenai resep masakan yang memiliki nilai ekonomi tersebut dicuri kemudian ditiru oleh pelaku usaha lain, sehingga kerugian pada pemilik rahasia dagang dan keuntungan tidak sehat bagi pelaku usaha yang curang.

Perlindungan terhadap rahasia dagang memiliki kelebihan dan kekurangan. Keuntungan perlindungan rahasia dagang, yaitu: (a) Tidak ada biaya untuk pendaftaran (rahasia dagang tidak didaftarkan), biaya hanya ada untuk pencantuman pengalihan atau pencatatan perjanjian lisensi rahasia dagang; (b) Perlindungan rahasia dagang tidak memerlukan adanya pengungkapan rahasia (berbeda dengan paten); (c) Perlindungan rahasia dagang tidak memiliki jangka waktu. Rahasia dagang akan selalu mendapat perlindungan selama si pemilik rahasia terus menerus menjaga kerahasiaannya; (d) Rahasia dagang memiliki 
efek langsung bagi perusahaan. Bagi resep atau formula dari suatu produk merupakan aset penting bagi perusahaan. Rahasia dagang merupakan aset yang sangat penting bagi perusahaan karena berkaitan dengan kelangsungan perusahaan tersebut. Kerugian melindungi informasi dengan menggunakan rahasia dagang, yaitu: (a) Pihak lain dapat melakukan reverse engineering, dan itu sah menurut hukum Indonesia; (b) Sulitnya penegakan hukum rahasia dagang, bisa saja perlindungan rahasia dagang berakhir apabila trade secret tidak dilakukan upaya atau langkah-langkah nyata untuk melindunginya.

\section{Simpulan}

Rahasia dagang adalah informasi yang tidak diketahui oleh umum di bidang teknologi dan/atau bisnis, mempunyai nilai ekonomi karena berguna dalam kegiatan usaha, dan dijaga kerahasiaanya oleh pemilik rahasia dagang. Rahasia dagang sudah mendapat perlindungan hukum tanpa harus didaftarkan ke dalam Direktorat Jenderal Kekayaan Intelektual akan tetapi pemilik atau pemegang hak rahasia dagang wajib menyimpan kerahasiaan rahasia dagang dengan baik agar tidak diketahui oleh masyarakat secara umum. Walaupun tanpa harus didaftarkan rahasia dagang sudah mendapatkan perlindungan hukum di Direktorat Jenderal Kekayaan Intelektual Kementerian Hukum dan HAM Jawa Tengah, tetapi ada yang mendaftarkan Rahasia Dagang. Hal itu dikarenakan agar pemilik dan pemegang hak rahasia dagang mempunyai pembuktian yang kuat ketika suatu saat terjadi perselisihan.

Setiap negara melindungi rahasia dagang secara bervariasi, secara umum rahasia dagang melindungi semua jenis informasi rahasia, apakah itu komersial, industri, atau pribadi. Rahasia dagang masuk dalam kekayaan intelektual, di samping merek, paten, desain industri, dan hak cipta. Siapapun yang memiliki informasi berkonsep rahasia dapat terlindungi, karena rahasia dagang masuk dalam kategori kekayaan intelektual. Meskipun demikian trade secret memiliki perbedaan dengan kekayaan intelektual lainnya. Perlindungan hukum rahasia dagang sudah ter-cover baik menggunakan hukum pidana atau pun hukum perdata, secara pidana orang atau badan hukum perdata yang barang siapa yang sengaja secara melawan hukum mengungkapkan rahasia dagang, mengingkari kesepakatan atau mengingkari kewajiban tertulis atau tidak tertulis untuk menjaga rahasia dagang yang bersangkutan dipidana penjara paling lama 2 (dua) tahun dan/ atau denda paling banyak Rp.300.000.000,00 (tiga ratus juta rupiah) dan ketentuan ini merupakan delik aduan. Selain menggunakan dengan hukum pidana dapat juga di selesaikan menggunakan hukum perdata dimana gugatan di jukan ke Pengadilan Negeri.

\section{Daftar Pustaka}

Choudhary, Sarika, et al, Program and Data Protection: Copyright, Patent, Trade Secret and Trademark, Indian Journal of Computer Science and Engineering (IJCSE), ISSN : 0976-5166 Vol. 4 No.3 Jun-Jul 2013, halaman 235-239.

Chazawi, Adami, 2007, Tindak Pidana Hak Atas Kekayaan Intelektual (HAKI), Bayu Media Publishing, Malang

I Made Udiana, I. Made, 2011, Rekonstruksi Pengaturan Penyelesaian Sengketa Penanaman Modal Asing, University Press, Udayana

Friedman, David D., William M. Landes, and Richard A. Posner. 1991. "Some Economics of Trade Secret Law." Journal of Economic Perspectives, 5 (1): 61-72.

Jened, Rahmi, Janed, 2010, Hak Kekayaan Intelektual, Airlangga University Press, Surabaya

John Hull; Trade secret licensing: the art of the possible, Journal of Intellectual Property Law \& Practice, Volume 4, Issue 3, 1 March 2009, Pages 203-212, https:// doi.org/10.1093/jiplp/jpn251

Lindsey, Tim, Lindsey, 2013, Hak Kekayaan Intelektual, PT. Alumni, Bandung

Margono, Suyud \& Amir Angkasa, 2002, Komersialisasi Aset Intelektual (Aspek Hukum Bisnis), PT. Gramedia Widyasarana Indonesia, Jakarta

Maulana, Insan Budi, Maulana Insan, 2001, Langkah Awal Mengenal UndangUndang Rahasia Dagang, PT. Citra 
Aditya Bakti, Bandung

Michael Risch, Why Do We Have Trade Secrets?, 11 Intellectual Property L. Rev. 1 (2007). Available at: http:// scholarship.law.marquette.edu/iplr/ vol11/iss $1 / 1$

OK., Saidin, 2004, Aspek Hukum Hak Kekayaan Intelektual, PT. Raja Grafindo Persada, Jakarta

Robert G. Bone, A New Look at Trade Secret Law: Doctrine in Search of Justification, 86 Calif. L. Rev. 241 (1998). https:// doi.org/10.15779/Z38942G

Robert G. Bone, The (Still) Shaky Foundations of Trade Secret Law, Texas Law Review, Vol. 92:1803-1838 (2014).

Ramli, Ahmad M., 2000, H.A.K.I: Teori Dasar Perlindungan Rahasia Dagang, Mandar Maju, Bandung

------------------, 2001, Perlindungan Rahasia Dagang dalam UUNo. 30/2000 dan Perbandingan dengan beberapa Negara, CV. Bandar Maju, Bandung, 2001.

Sudaryat, dkk. 2010. Hak Kekayaan Intelektual Memahami Prinsip Dasar. Cakupan dan Undang-Undang yang berlaku, Oase Media, Bandung

Utomo, Tomy Suryo, 2010, Hak Kekayaan Intelektual (HKI), Graha Ilmu, Yogyakarta 